\title{
Effect of amount and time of incorporation of forest litter on soil physical properties
}

\author{
Paardensha Ivy Chinir, Manoj Dutta, Rizongba Kichu and Sewak Ram
}

Received : 14.08.2020; Revised : 02.11.2020; Accepted : 16.11 .2020

MEMBERS OF RESEARCH FORUM:
Corresponding author :
Manoj Dutta, Department of Soil and
Water Conservation, School of
Agricultural Sciences and Rural
Development, Nagaland University,
Medziphema Campus, Medziphema
(Nagaland) India
Email: manojdutta1997@yahoo.com

Co-authors :

Paardensha Ivy Chinir, Rizongba Kichu and Sewak Ram, Department of Soil and Water Conservation, School of Agricultural Sciences and Rural Development, Nagaland University, Medziphema Campus, Medziphema (Nagaland) India E mail: ivychinir@gmail.com; rizong09@gmail.com; sewaksasrd@gmail.com

\section{Summary}

A field experiment was conducted to evaluate the effect of forest litter and its time of incorporation on soil physical properties. The study showed that plots with forest litter incorporated at 45 DBS (Days Before Sowing) had significantly higher soil moisture content as compared to those incorporated at 30 DBS after 30 and 60 DAS. However, the difference in the time of incorporation had no significant effect on soil moisture content at 90 DAS. At 30 DAS, application of forest litter @ $6 \mathrm{t} \mathrm{ha}^{-1}$ and $9 \mathrm{t} \mathrm{ha}^{-1}$ significantly increased the soil moisture content at a rate of 4.11 and 11.42 per cent, respectively over control. At 60 DAS, application of forest litter@ $3 \mathrm{t} \mathrm{ha}^{-1}, 6 \mathrm{t} \mathrm{ha}^{-1}$ and $9 \mathrm{t} \mathrm{ha}^{-1}$ significantly increased the soil moisture content at the rate of 15.05, 17.26 and 25.65 per cent, respectively over control. At 90 DAS, a trend was noticed which showed that soil moisture content significantly increased at a progressive rate with each increase in the dose of forest litter application. At 90 DAS, the addition of forest litter@3 t ha ${ }^{-1}, 6$ tha $^{-1}$ and 9 t ha $^{-1}$ increased the soil moisture content @ 10.16, 17.84 and 22.20 per cent, respectively over control. The plots with forest litter incorporated at 45 DBS had significantly higher hydraulic conductivity, per cent aggregates and mean weight diameter as compared to those incorporated at 30 DBS. However, the difference in the time of incorporation i.e., at 30 and 45 DBS had no significant effect on bulk density, particle density and water holding capacity. Incorporation of forest litter @ $3 \mathrm{t} \mathrm{ha}^{-1}, 6 \mathrm{t} \mathrm{ha}^{-1}$ and $9 \mathrm{t} \mathrm{ha}^{-1}$ significantly decreased the bulk density at the rate of $3.67,8.65$ and 14.14 per cent; while particle density increased at the rate of $2.59,3.42$ and 6.61 per cent, respectively when compared to control. The addition of forest litter @ $3 \mathrm{tha}^{-1}, 6 \mathrm{tha}^{-1}$ and $9 \mathrm{t} \mathrm{ha}^{-1}$ resulted in a significant increase in water holding capacity and hydraulic conductivity at a rate of $3.72,4.65$ and 6.77 per cent and $24.13,32.30$ and 41.73 per cent, respectively over control. Further, the application of forest litter@3 ha $\mathrm{th}^{-1}, 6 \mathrm{t} \mathrm{ha}^{-1}$ and $9 \mathrm{t} \mathrm{ha}^{-1}$ significantly increased the per cent aggregate and mean weight diameter of the soil @ 1.77, 3.49 and 6.58 per cent 17.31, 26.28 and 41.35 per cent, respectively over control. The study revealed that incorporating $9 \mathrm{t} \mathrm{ha}^{-1}$ of forest litter at 45 DBS had the most beneficial effect on soil physical properties.

Key words : Forest litter, Time of incorporation, Soil physical properties

How to cite this article : Chinir, Paardensha Ivy, Dutta, Manoj, Kichu, Rizongba and Ram, Sewak (2020). Effect of amount and time of incorporation of forest litter on soil physical properties. Asian J. Soil Sci., 15(2): 68-74: DOI:10.15740/HAS/AJSS/15.2/68-74. Copyright@2020: Hind Agri-Horticultural Society. 